\title{
STUDIES ON THE EFFECT OF POLLUTION ON LAKE MANZALA ECO- SYSTEM IN PORT-SAID, DAMIETTA AND DAKAHLIA GOVERNORATES, EGYPT
}

\section{By}

HANAA M.M. EL-KHAYAT ${ }^{1}$, KADRIA M.A. MAHMOUD ${ }^{1}$, HANAN S. GABER ${ }^{2}$, HODA ABDEL-HAMID ${ }^{1}$ AND HODA M.A. ABU TALEB ${ }^{1}$

Department of Environmental Researches and Medical Malacology ${ }^{1}$, Theodor Bilharz Research Institute, Imbaba P.O. Box 30, Giza, and National Institute of Oceanography and Fisheries ${ }^{2}$, Cairo, Egypt.

\begin{abstract}
This work studied how pollution impacts the ecosystem of Lake Manzala by determination of physicochemical parameters, studying biodiversity of aquatic plants and macroinvertebrates, and determining bioaccumulation of $\mathrm{Pb}, \mathrm{Cu}, \mathrm{Cd} \& \mathrm{Zn}$ in some major organisms, Biomphalaria alexandrina and Melanoides tuberculata snails and Oreochromis niloticus fish. The more near to Mediterranean Sea and to the industrial area, Port-Said and Damietta sites showed higher dissolved oxygen and conductivity than Dakahlia sites. Distribution percentage of Eichhornia crassipes is high among Port-Said and Dakahlia sites of 100 and $88 \%$, respectively, while Lemna giba is the most abundant among Damietta sites of $60 \%$. The maximum macroinvertebrate taxa richness was obtained at Gammalya, Dakahlia of 16 species while the maximum abundance was registered at Annanya, Damietta of 591 organisms. Gastropoda are the most distributed organisms in Lake Manzala followed by Hemiptera and Plecoptera then shrimps and scud. All the medically important snails, B. alexandrina, B. truncatus and L. natalensis were recorded in Dakahlia, but only B. alexandrina was in Damietta and Port-Said sites. The collected water samples from Damietta sites showed the highest significant $\mathrm{Cu} \& \mathrm{Cd}$ concentration while Port-Said samples showed the highest $\mathrm{Pb}$ concentration and Dakahlia showed the highest $\mathrm{Zn}$ concentration. The metals concentrations were higher in snail tissue and in fish liver, kidney and most of muscle samples as compared in surface water. The higher metal bioaccumulation was determined in snails collected from sites showed higher water metals concentrations. Fish muscle showed the least residues than liver and kidney for all the measured metals. $\mathrm{Pb}$ and $\mathrm{Cd}$ were more accumulated in kidneys, $\mathrm{Cu}$ was more accumulated in liver and $\mathrm{Zn}$ was accumulated in all examined fish parts in descending order as follows Kidney $>$ liver $>$ muscle.

Key wards: Lake Manzala, Biomphalaria alexandrina snails, Nile tilapia Oreochromis niloticus, heavy metals $(\mathrm{Cu}, \mathrm{Cd}, \mathrm{Pb}$ and $\mathrm{Zn})$.
\end{abstract}

\section{Introduction}

The ecological damage of the aquatic environment are mainly related to anthropogenic factors as well as the presence of hazardous, infections and parasitizing agents (SilveiraCohignya et al., 2004). Aquatic biota, sediments, and water samples may be used for pollution-monitoring purposes (Porte and Albaiges, 1993). Recently several investigators study the impact of chemical characteristics of water on fresh water macroinvertebrates (Buss and Borges, 2008; Sola et al, 2004; Stone et al, 2008; Van Damme et al, 2008). Also, Muncaster et al. (1990) recommended that whereas water contaminant levels are usually below detection limits therefore, living organisms should also be used to monitor environmental contamination, since they may reflect the contamination history of a particular location because they have been exposed during their entire lifetime and are capable of accumulating these toxic substances in their lipid tissue fractions. Metal bioaccumulation can be of importance from the public health point of view, especially when a human consumes the accumulators. The benthic gastropods in wetlands have an especially close relationship with the sediments that comprises their habitat and feeding site. Gastropods in turn are used as food source by birds and fish, which in turn make them accessible for hu- 
man consumption through food chain and eventually pose great health risk (Altindag and Yigit, 2005). Lake Manzala is considered one of the most important lakes in Egypt. It is exposed to high levels of pollutants from industrial, domestic and agricultural resources (Badawy and Wahaab, 1997; Abdel-Baky et al, 1998bl; Ibrahim et al, 1999b). Ali (2008) reported that Lake Manzala receives about 4000 million cubic meters of untreated industrial, domestic and agricultural drainage water, discharged annually into the lake through several drain; Bahr El-Bakar Drains (domestic and industrial sewage), Hadous, Ramsis, El-Serw and Faraskour Drains (agricultural effluents). These drains maintained high heavy metals levels which exceed than the allowed maximum concentration reported by Word Health Organization, which might cause a public health problem (Abdel-Satar, 2001). Also, Bishai and Yossef (1977) reported that drains inlet to Lake Manzala gradually transformed, with time, its brackish environment to eutrophic fresh water that can be breeding sites for many freshwater organisms including snails that transmit schistosomiasis, $B i$ omphalaria alexandrina and Bulinus truncatus and fascioliasis, Lymnaea species. In Egypt, schistosomiasis is not only a prime health problem, but it is also an economic one, as it affects people at the early age diminishing their productivity and exerting a serious socioeconomic problem (El-Baz et al., 2003). Also, fascioliasis in Egypt is highly enzootic affecting cattle, sheep, donkeys, goats and buffaloes and estimating severe negative economic impact (Mazyad and El-Nemr, 2002; Awad et al, 2004; Morsy et al, 2005; Haridy et al, 2006). In addition, human fascioliasis constitutes a significant health problem, as the estimated number of people infected with fascioliasis in Egypt is 830,000 cases (Aseeb et al, 2002), while population at risk is considered to be 27 million (WHO, 2007).

The objective of the present study was to study how pollution impacts an ecosystem of Lake Manzala, through determining physicochemical parameters, studying biodiversity and distribution of aquatic plants, macroinvertebrates and medically important snails and determining bioaccumulation of $\mathrm{Pb}, \mathrm{Cu}, \mathrm{Cd}$ and $\mathrm{Zn}$ in some major organisms.

\section{Materials and Methods}

This study was carried out in 14 different sites in Lake Manzala in three governorates; Port Said (5 sites), Dakahlia (6 sites) and Damietta (3 sites) in North Delta, Egypt (Fig. 1).

Samples collection: A survey of the water banks was carried out in the sites from May 2013 to end of May 2014 utilizing a motorized boat, from which live samples of macroinvertebrates including snails were collected and their water ecological conditions were recorded (e.g. temperature and conductivity measured in the selected watercourses by temperature conductivity meter (HANNA instrument, HI 9635). Also, Hydrogen ion concentration $(\mathrm{pH})$ measured by $\mathrm{pH}$-meter (HI 8543). Dissolved oxygen was measured by oxygen meter (HANNA HI 9146). From each site samples resemble all of macrophyte species were collected. In the lab the macrophytes were sorted and identified according to Madsen (1994). Macroinvertebrate organisms clinging to aquatic vegetation or free swimming were collected using the kick and shuffle method by $500 \mu \mathrm{m}$ mesh D-Form dip net (Robinson, 2004 and Takougang et al., 2008) and the collected samples from each site were placed in separate plastic aquaria then transferred to the laboratory, where they were sorted out, taxonomically identified to the lowest possible taxonomic level (Hauer and Lamberti, 1996; Leska, 1998; Bouchard, 2004) then number of each taxon were calculated. Taxa Richness (TR) equals the total number of taxa represented within the sample. Fish samples were collected with the help of professional local fishermen. Also, water samples were collected in 1 liter polyethylene bottles from sites under study, to determine the concentr- 
ations of $\mathrm{Pb}, \mathrm{Cu}, \mathrm{Zn} \& \mathrm{Cd}$.

Accumulation of heavy metals: Snails were dissected within $12 \mathrm{hr}$ of collection and the whole body tissues were removed and fish were dissected to get muscle, liver, kidney within one hour. The dissected tissues dried at about $80^{\circ} \mathrm{C}$ in an electric oven. After complete drying the tissues were pulverized in clean dry mortar and stored separately by labeling the specimen with date and species name. Samples of whole fish were dried at $105^{\circ} \mathrm{C}$ for a period of $36 \mathrm{hr}$ then powdered. One gram of each dried tissues was transferred to clean screw capped glass bottle and digested with $10 \mathrm{ml}$ of solution HNO3-
HClO4 (4:1 v/v) (FAO, 1983). Initial digestion was conducted for four hours at room temperature, followed by heating at $40-45^{\circ} \mathrm{C}$ for one hour in water bath, then raised to $70^{\circ} \mathrm{C}$ until the end of digestion. After cooling at room temperature the digest was diluted to $25 \mathrm{ml}$ with deionized water and filtered in volumetric flask to determine the concentrations of the examined heavy metals. In the Environmental Research laboratory, Theodor Bilharz Research Institute the specimen of snails, fish and water were analyzed for the levels of cadmium, lead, zinc and copper using, Avanta Atomic Absorption Spectrophotometer.

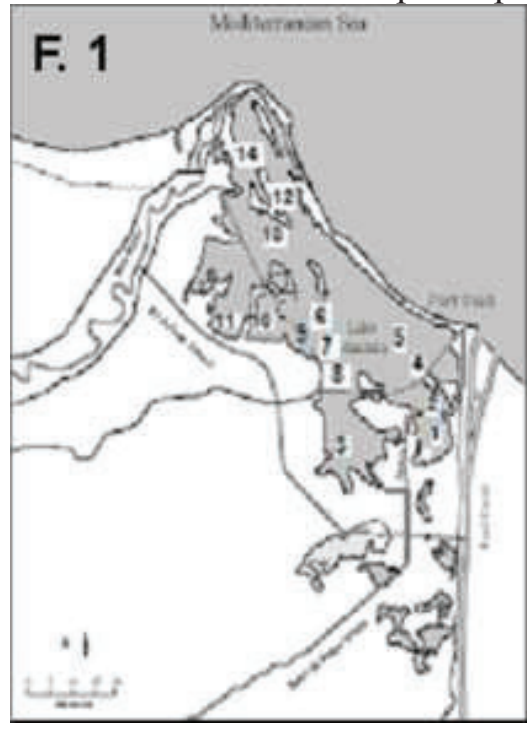

Fig. 1: Sites of Lake Manzala in Port-Said, Damietta and Dakahlia Governorates. Port-Said sites: 1: Bahr ElBakar, 2: Kobry El-Lansh, 3: El-Khandk, 4: El-Treek El-Dawly and 5: El-Temsah; Dakahlia sites 6: El-Dela, 7: Ibn-Salam, 8: Matarya, 9: Nasayma, 10 Deshda and 11 Gammalya \& Damietta sites 12 Anannya, 13: Sayyala and 14: Izbet El-Borg.

Statistical analysis: One-way ANOVA and Duncan multiple range test were used to evaluate the significant difference in the concentration of different studied metals with respect to different sites. A probability at level of 0.05 or less was considered significant (Bailey, 1981). Standard errors were also estimated. Data were carried out using Instate software computer program, VERSION 5.03 (Graph pad, USA) and IBMPC compatible computer.

\section{Results}

In physicochemical parameters (Fig. 2), temperature ranged between $21^{\circ} \mathrm{C}$ and $31^{\circ} \mathrm{C}$, higher values were recorded in Sayyala, Damietta during spring season. The lowest temperature $\left(21^{\circ} \mathrm{C}\right)$ was in El-Temsah, Port-Said and Ibn-Salam, Dakahlia during autumn. Port-Said and Damietta sites have higher dissolved oxygen concentration with maximum concentration of $12.5 \& 12.1 \mathrm{mg} / 1$ in El-Temsah and Syala sites, respectively while lowest value of $2.6 \mathrm{mg} / 1$ was obtained in Matarya, Dakahlia. Conductivity varied between 1800 to $270 \mu \mathrm{mhos} / \mathrm{cm}$. Low-er conductivity values were obtained at Ga- 
mmalya, Dakahlia, but the highest value was obtained at El-Temsah, Port-Said. Most sites of Damietta have intermediate values with maximum value of $11000 \mu \mathrm{mhos} / \mathrm{cm}$ in
Ananya site. Hydrogen ion concentration values increased from 7.1 at Kobry ElLansh, Port-Said to 8.2 at Nasayma, Dakahlia to 8.6 at Sayyala, Damietta.

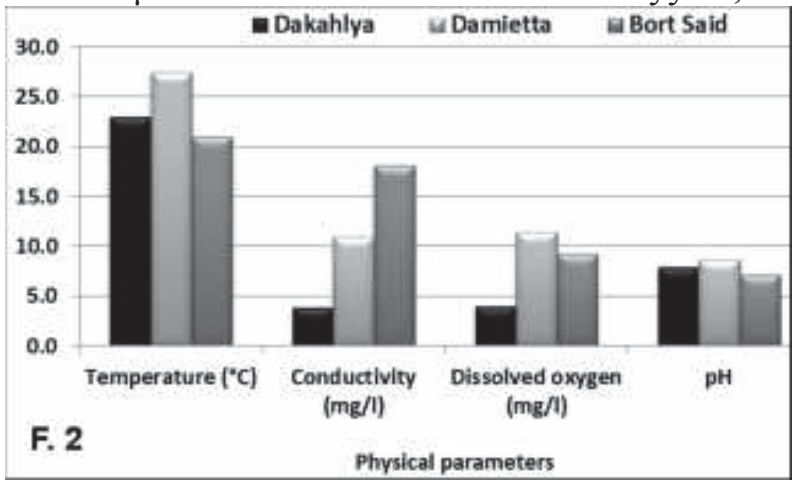

Fig. 2: One year survey means of physicochemical parameters at sites in Lake Manzala in three governorates.

The chemical parameters (Tab. 1) showed that the $\mathrm{Pb}, \mathrm{Cu}$ and $\mathrm{Cd}$ concentration in all Port-Said and Damietta sites exceeded the higher limit that was determined by of EPA (2011) with while only Deshda among Dakahlya sites exceeded the higher limit for $\mathrm{Cu}$ and $\mathrm{Cd}$.

Statistical analysis revealed that the concentration of the chemical parameters in Damietta sites was the higher, significantly, than the other tested governorates. Lead increased significantly at $\mathrm{p}<0.001$ in Sayyala than Kobry El-Lansh, Bahr El Bakar, Ezbet El-Borg \& Ananya and at $\mathrm{p}<0.01$ than El-
Khankad and at $\mathrm{p}<0.05$ than EL_Tareek ElDawly. Copper was significantly increased in Ezbet El-Borg than Bahr El Bakr, Deshda, Matereya at $p<0.001$, while it increased at $\mathrm{p}<0.05$ in Sayyala than Gammalya and Ananeya. Also, the concentration of zinc was increased significantly in Sayyala than El-Khankad, Bahr El Bakar, E;-Tareek ElDawly, Ezbet El-Borg, Gammalya and Ananya $(\mathrm{p}<0.01)$. In addition, cadmium recorded significant increase $(p<0.001)$ in Ezbet El-Borg than Sayyala, El-Khankad, Bahr El Bakar, El-Tareek El-Dawly, Gammalya, Bahr El Bakr and Ananeya

Table 1: Concentrations ( $\mathrm{M} \pm \mathrm{SE}$ ) of $\mathrm{Pb}, \mathrm{Cu}, \mathrm{Zn}$ and $\mathrm{Cd}$; and their folds over national level of concern (CL); in water samples collected at different sites in three governorates (Gov.) at Lake Manzala over one year.

\begin{tabular}{|c|c|c|c|c|c|c|c|c|c|}
\hline Gov. & Sites & $\begin{array}{c}\mathrm{Pb} \\
(\mathrm{ppb})\end{array}$ & $\begin{array}{l}\text { Folds } \\
\mathrm{M} / \mathrm{CL}\end{array}$ & $\begin{array}{c}\mathrm{Cu} \\
(\mathrm{ppb})\end{array}$ & $\begin{array}{l}\text { Folds } \\
\text { M/CL }\end{array}$ & $\begin{array}{c}\mathrm{Zn} \\
(\mathrm{ppm})\end{array}$ & $\begin{array}{l}\text { Folds } \\
\text { M/CL }\end{array}$ & $\mathrm{Cd}(\mathrm{ppb})$ & $\begin{array}{l}\text { Folds } \\
\mathrm{M} / \mathrm{CL}\end{array}$ \\
\hline \multirow{4}{*}{$\begin{array}{l}\text { Port- } \\
\text { Said }\end{array}$} & El-Khandak & $114.0 \pm 31.4$ & 1.8 & $16.4 \pm 21.2$ & 1.3 & $0.5 \pm 0.2$ & 4.2 & $10.4 \pm 10.6$ & 5.2 \\
\hline & El-Tareek El-Dawly & 110.00 & 1.7 & 98.61 & 7.6 & 0.06 & 0.5 & 3.99 & 2.0 \\
\hline & Kobry El-Lansh & $100.47 \pm 40.61$ & 1.6 & $156.18 \pm 261.68$ & 12.0 & $0.28 \pm 0.07$ & 2.3 & $5.38 \pm 5.24$ & 2.7 \\
\hline & Bahr El-Baar & $73.67 \pm 45.39$ & 1.2 & $28.73 \pm 14.35$ & 2.2 & $0.32 \pm 0.17$ & 2.7 & $5.23 \pm 5.42$ & 2.6 \\
\hline \multicolumn{2}{|c|}{ Port-Said } & $99.54 \pm 18.15$ & 1.6 & $74.98 \pm 65.12$ & 5.8 & $0.29 \pm 0.14$ & 2.4 & $6.25 \pm 2.84$ & 3.1 \\
\hline \multirow{3}{*}{$\begin{array}{l}\text { Da- } \\
\text { kahlia }\end{array}$} & Deshda & $50.84 \pm 48.40$ & 0.8 & $26.63 \pm 6.17$ & 2.0 & $0.33 \pm 0.25$ & 2.8 & $6.83 \pm 3.81$ & 3.4 \\
\hline & Gammalya & 8.75 & 0.1 & 6.31 & 0.5 & 0.84 & 7.0 & 2.87 & 1.4 \\
\hline & Matarya & $39.22 \pm 15.25$ & 0.6 & $6.88 \pm 1.156$ & 0.5 & $0.19 \pm 0.02$ & 1.6 & $1.77 \pm 1.99$ & 0.9 \\
\hline \multicolumn{2}{|c|}{ Dakahlia } & $32.94 \pm 21.74$ & 0.5 & $13.27 \pm 11.57$ & 1.0 & $0.45 \pm 0.34$ & 3.8 & $3.82 \pm 2.66$ & 1.9 \\
\hline \multirow{3}{*}{$\begin{array}{l}\text { Dami- } \\
\text { etta }\end{array}$} & Ananya & $88.05 \pm 93.86$ & 1.4 & $106.69 \pm 140.27$ & 8.2 & $0.36 \pm 0.05$ & 3.0 & $4.35 \pm 5.03$ & 2.2 \\
\hline & Sayyala & $\begin{array}{c}191.50 \pm 2.12 \\
* * * * * * \\
,, \\
\end{array}$ & 3.0 & $\begin{array}{c}207.70 \pm 227.12 \\
*\end{array}$ & 16.0 & $\begin{array}{c}0.63 \pm 0.39 \\
* *\end{array}$ & 5.3 & $9.69 \pm 0.04$ & 4.8 \\
\hline & Ezbet El-Borg & 70.13 & 1.1 & $315.30 \pm 0$ & 24.3 & 0.32 & 2.7 & $\begin{array}{c}306.60 \pm 0 \\
* * *\end{array}$ & 153.3 \\
\hline \multicolumn{2}{|c|}{ Damietta } & $116.56 \pm 65.52$ & 1.9 & $209.90 \pm 104.32$ & 16.1 & $0.44 \pm 0.17$ & 3.6 & $\begin{array}{c}106.88 \pm 172 . \\
98\end{array}$ & 53.4 \\
\hline \multicolumn{2}{|c|}{ Lake Manzala } & $84.66 \pm 49.98$ & 1.3 & $96.943 \pm 103.26$ & 7.5 & $0.38 \pm 0.22$ & 3.2 & $35.71 \pm 95.22$ & 17.9 \\
\hline \multicolumn{2}{|c|}{$P L$} & \multicolumn{2}{|l|}{$65 \mathrm{ppb}$} & \multicolumn{2}{|l|}{$13 \mathrm{ppb}$} & \multicolumn{2}{|c|}{$120 \mathrm{ppb}$} & \multicolumn{2}{|l|}{$2 \mathrm{ppb}$} \\
\hline
\end{tabular}

$P L$ : permissible limits according to EPA (2011), All values = means (M) \pm standard error (SE); with different letters; statistically significant extremely significant at ${ }^{* * *} p<0.001$ level; $^{* *} \mathrm{P}<0.01$ highly significant and ${ }^{*} p<0.05$ significant. 


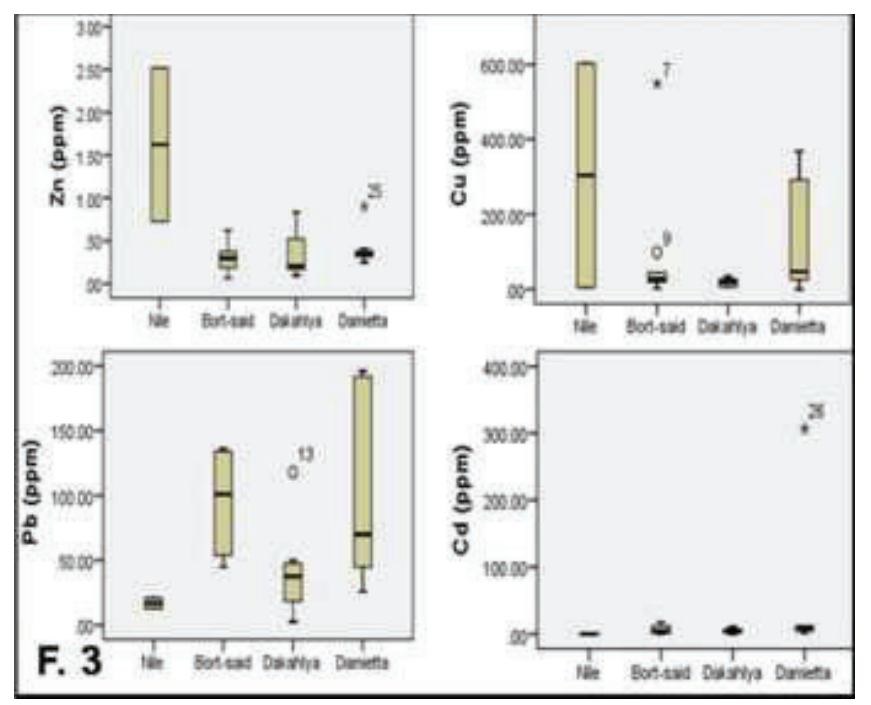

Fig. 3: Box plots of the heavy metals $\mathrm{Zn}, \mathrm{Cd}, \mathrm{Cu}$ and $\mathrm{Pb}$ according to the Port-Said, Dakalia and Damietta. Box represents interquartile range; top and bottom of box respectively $25^{\text {th }} \& 75^{\text {th }}$ percentile, Line across box median, Circles represent outliers.

Aquatic plants: Aquatic plants survey of Lake Manzala showed a total of seven species, Eichhornia crassipes, Ceratophyllum demersum, Jussiaea repens, Lemna giba, Pistia stratiotes, Phragmites and Bermuda grass. E. crassipes is the most abundant in Lake Manzala followed by Phragmites and
C. demersum then L. giba and P. stratiotes while $J$. repens and Bermuda grass showed a limited distribution (Fig 4). E. crassipes is the most abundant among Port-Said and Dakahlia site of 100 and $88 \%$ distribution percentage, respectively, followed by $L$. giba among Damietta sites of $60 \%$.

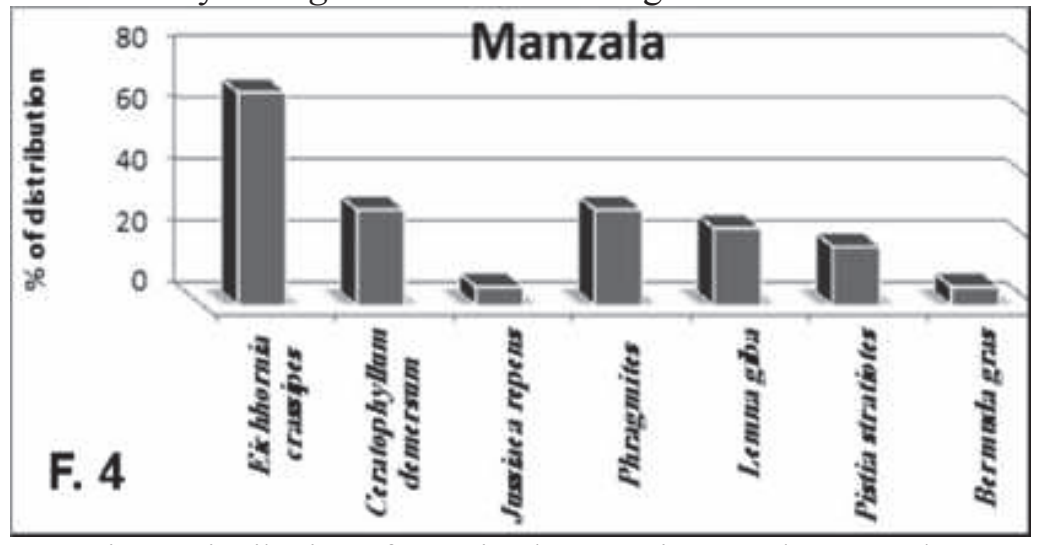

Fig.4: Distribution of aquatic plant species at Lake Manzala.

The macroinvertebrate and freshwater snail distribution patterns (Tab. 2 \& Fig. 5), showed total number of living organisms captured was 1410 with taxa richness of 20 . Macroinvertebrates were identified as gastropoda, 829 (60.04\%), Shrimp, 246 (17.52\%), Scud, 154 (10.97\%), Hemiptera, 78 (5.56\%), Plecoptera, 77 (5.48\%), Damselfly and Maggot larvae, each $5(0.36)$ and Dragon fly and Crayfish, each 1 (0.07\%).
Gastropoda are the most distributed organisms in Lake Manzala followed by Hemiptera and Plecoptera then shrimps and scud. Each of crayfish, Damselfly, Dragon fly and magot larvae showed limited distribution. The maximum macroinvertebrates taxa richness was determined in Gammalya, Dakahlia (16 species), while the maximum abundance was recorded at Annanya, Damietta of 591 organisms (20 species). Gastropoda 
was the most distributed in Dakahlia and Damietta, while shrimps and Hemiptera is the most distributed in Port-Said followed by Gastropoda. Total number of organisms captured was 843 with taxa richness of 10 , resulting in an average snail density of 39.476 snails/site. The maximum snail taxa richness was obtained at Gammalya, Dakahlia of 9 species while the maximum abundance was obtained at Annanya, Damietta of 240 snails, (table $2 \&$ fig. 4). Snails were identified as Planorbis planorbis, 290 (34.40\%), Biomphalaria alexandrina, 254 (30.13\%), Physa acuta, 216 (25.62\%), Melanoides tuberculata, 51 (6.05\%), Lymnaea natalensis, 10 (1.19\%), Lanistes carinatus, 7 (0.83\%), Cleopatra bulimoides, 6 (0.71\%), Bulinus truncatus, 5 (0.59\%), Bellamya unicolor, $3(0.36 \%)$ and Helisoma duryi, 1 (0.12). B. alexandrina and P. planorbis are the most distributed in Lake Manzala fol- lowed by $P$. acuta, C. bulimoides, L. natalensis and $M$. tuberculata then $B$. truncatus and L. carinatus. Each of B. unicolor and $H$. duryi showed limited distribution in the lake. C. bulimoides, P. planorbis and B. alexandrina are the most distributed in Dakalya, $P$. planorbis is the most distributed in Damietta and each of $P$. planorbis, B. alexandrina and $P$. acuta are the most distributed in Port-Said.

The medically important snails' distribution (Fig. 6), were B. alexandrina, B. truncatus and L. natalensis were recorded in Dakahlia while $B$. alexandrina only was recorded in Damietta and Port-Said sites. Active transmitting sites were recorded for $S$. mansoni in El-Khandak, Port-Said and Nasayma, Dakahlia with natural infection of 7 \& $6 \%$, respectively in collected $B$. alexandrina.

Table 2: Regional distribution of total snails and macroinvertebrates at different governorates at Lake Manzala.

\begin{tabular}{|c|c|c|c|c|c|c|c|c|c|c|c|c|}
\hline \multirow{2}{*}{\multicolumn{2}{|c|}{$\begin{array}{l}\text { Governorates } \\
\text { Biospecimens }\end{array}$}} & \multicolumn{4}{|c|}{ Dakahlia } & \multicolumn{2}{|c|}{ Damietta } & \multicolumn{3}{|c|}{ Port Said } & \multirow[b]{2}{*}{ 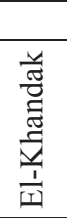 } & \multirow[b]{2}{*}{$\begin{array}{c}\% \text { in } \\
\text { total } \\
\text { sample }\end{array}$} \\
\hline & & 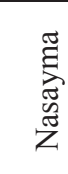 & 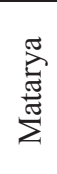 & 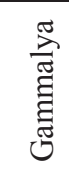 & 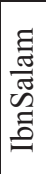 & $\sum_{\substack{\pi \\
\tilde{\pi}}}^{\frac{\pi}{\pi}}$ & 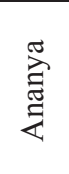 & 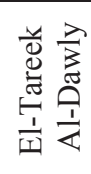 & 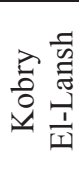 & 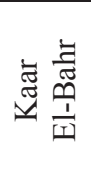 & & \\
\hline \multirow{10}{*}{$\begin{array}{c}\text { Snail } \\
\text { Species }\end{array}$} & L. carinatus & & 2 & 5 & & & & & & & & 0.83 \\
\hline & C. bulimoides & 2 & 2 & 2 & & & & & & & & 0.71 \\
\hline & P.planorbis & 50 & 10 & 20 & & 10 & 40 & & 60 & 100 & & 34.40 \\
\hline & B. alexandrina & 50 & 50 & 50 & & & & 10 & 30 & 50 & 14 & 30.13 \\
\hline & B. truncatus & & 3 & 2 & & & & & & & & 0.59 \\
\hline & L. natalensis & 2 & 1 & 7 & & & & & & & & 1.19 \\
\hline & P. acuta & 10 & & & & & 200 & & 1 & 5 & & 25.62 \\
\hline & H. duryi & & & 1 & & & & & & & & 0.12 \\
\hline & M. tuberculata & & & 50 & & & & & & 1 & & 6.05 \\
\hline & B. unicolor & & & 2 & 1 & & & & & & & 0.36 \\
\hline \multicolumn{2}{|c|}{ Snail taxa richness } & 5 & 6 & 9 & 1 & 1 & 2 & 1 & 3 & 4 & 1 & 10 \\
\hline \multirow{9}{*}{$\begin{array}{c}\text { Macro- } \\
\text { inverte- } \\
\text { brate } \\
\text { Taxa }\end{array}$} & Gastropoda & 114 & 68 & 139 & 1 & 10 & 240 & 10 & 91 & 156 & 14 & 60.04 \\
\hline & Cryfish & & & 1 & & & & & & & & 0.07 \\
\hline & Scud & & 10 & 50 & & & 94 & & & & & 10.97 \\
\hline & Shrimp & & 15 & 10 & & & 221 & & & & & 17.52 \\
\hline & Hemiptera & 7 & & 20 & & 11 & & & 10 & 30 & & 5.56 \\
\hline & Plecoptera & 15 & & 20 & & 1 & 31 & & 10 & & & 0.07 \\
\hline & Dragon fly & & & 1 & & & & & & & & 1.99 \\
\hline & Dameslfly & & & 5 & & & & & & & & 3.42 \\
\hline & Maggot larvae & & & & & & 5 & & & & & 0.36 \\
\hline \multicolumn{2}{|c|}{$\begin{array}{l}\text { Total number of collected } \\
\text { macro-invertebrates }\end{array}$} & 136 & 93 & 246 & 1 & 22 & 591 & 10 & 111 & 186 & 14 & 1411 \\
\hline \multicolumn{2}{|c|}{$\begin{array}{l}\text { Macro-invertebrate taxa } \\
\text { richness }\end{array}$} & 7 & 8 & 16 & 1 & 3 & 6 & 1 & 5 & 5 & 1 & 20 \\
\hline
\end{tabular}




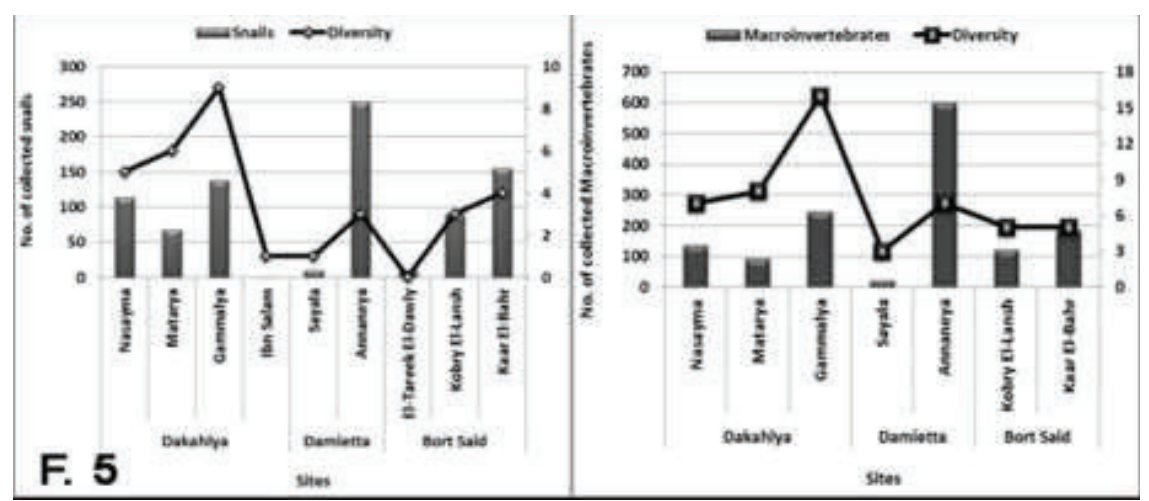

Fig. 5: Taxa richness and Diverstiy of macroinvertebrates \& freshwater snails in Lake Manzala in 3 governorates

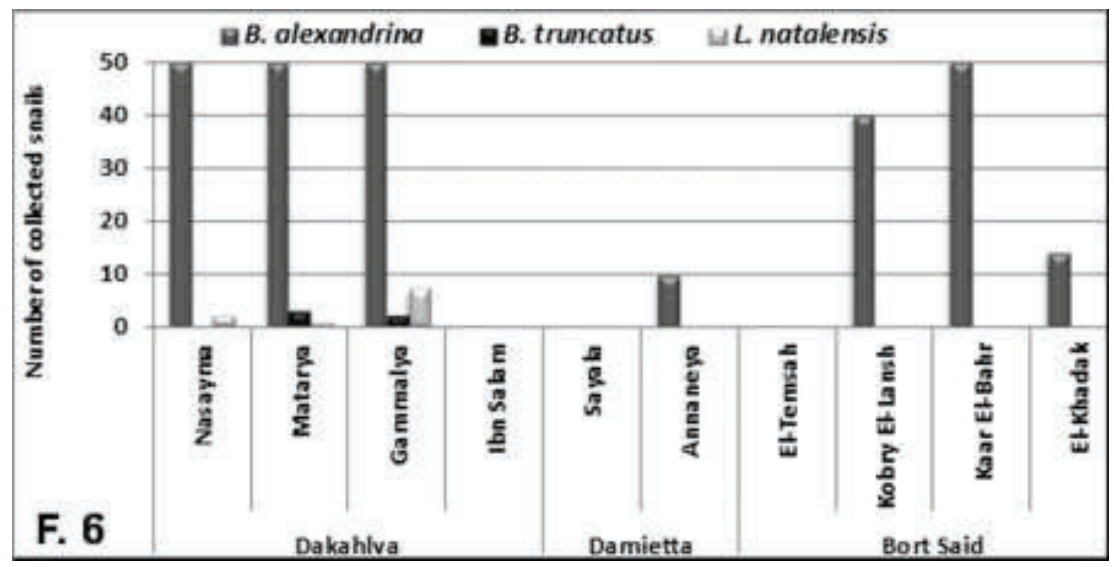

Fig. 6: Distribution and abundance of medically important snail within Lake Manzala sites of governorates.

Bioaccumulation of heavy metals in snails and fish samples: Levels of the heavy metals lead $(\mathrm{Pb})$, copper $(\mathrm{Cu})$, zinc $(\mathrm{Zn})$ and cadmium $(\mathrm{Cd})$ were determined in water surface of Lake Manzala, besides whole soft body tissues of both freshwater snail species (B. alexandrina \& M. tuberculata), also they measured in different organs of fish Oreochromis niloticus (muscle, liver and kidney). Results of $\mathrm{Pb}, \mathrm{Cu}, \mathrm{Zn}$ and $\mathrm{Cd}$ bioaccumulation levels in Biomphalaria and Melanoides snails are explored in (Fig. 7), it was highest in compared to its level in surface water. The studied snails collected from Kobry ElLansh and Port-Said governorate showed highest bioaccumulation of all metals. These results were co-parallel with the highest level of $\mathrm{Pb}, \mathrm{Cu} \& \mathrm{Cd}$ in water samples collected from same study sites whereas the highest Zn level was observed in Gammalya site followed Kobry El-Lansh site. When the capacity of bioaccumulation are compared between Biomphalaria and Melanoides (Fig.8) the metal concentration values exhibited that $B$. alexandrina have greater capacity for $\mathrm{Pb}$, $\mathrm{Cd}$ and $\mathrm{Zn}$ accumulation, while $M$. tuberculata has greater capacity for $\mathrm{Cu}$ accumulation.

The accumulation of heavy metals in studied fish organs (liver, kidney and muscle samples) showed higher concentrations than surface water (Fig. 9). $\mathrm{Pb} \& \mathrm{Cd}$ is more accumulated in kidneys and $\mathrm{Cu}$ is more accumulated in liver while $\mathrm{Zn}$ is accumulated in all examined fish parts in descending order: Kidney $>$ liver $>$ muscle. Kidneys of fish samples collected from Dakahlia (Matarya) showed the highest accumulation of $\mathrm{Pb}, \mathrm{Cd}$ and $\mathrm{Zn}$ than other sites of Lake Manzala, while liver of fish samples collected from Kobry El-Lansh showed the highest accumulation of $\mathrm{Cu}$ and $\mathrm{Zn}$. Also, results showed that in contrast to snails, the highest accumulation in fish tissue was not co-parallel with highest level in water samples in the same study sites 


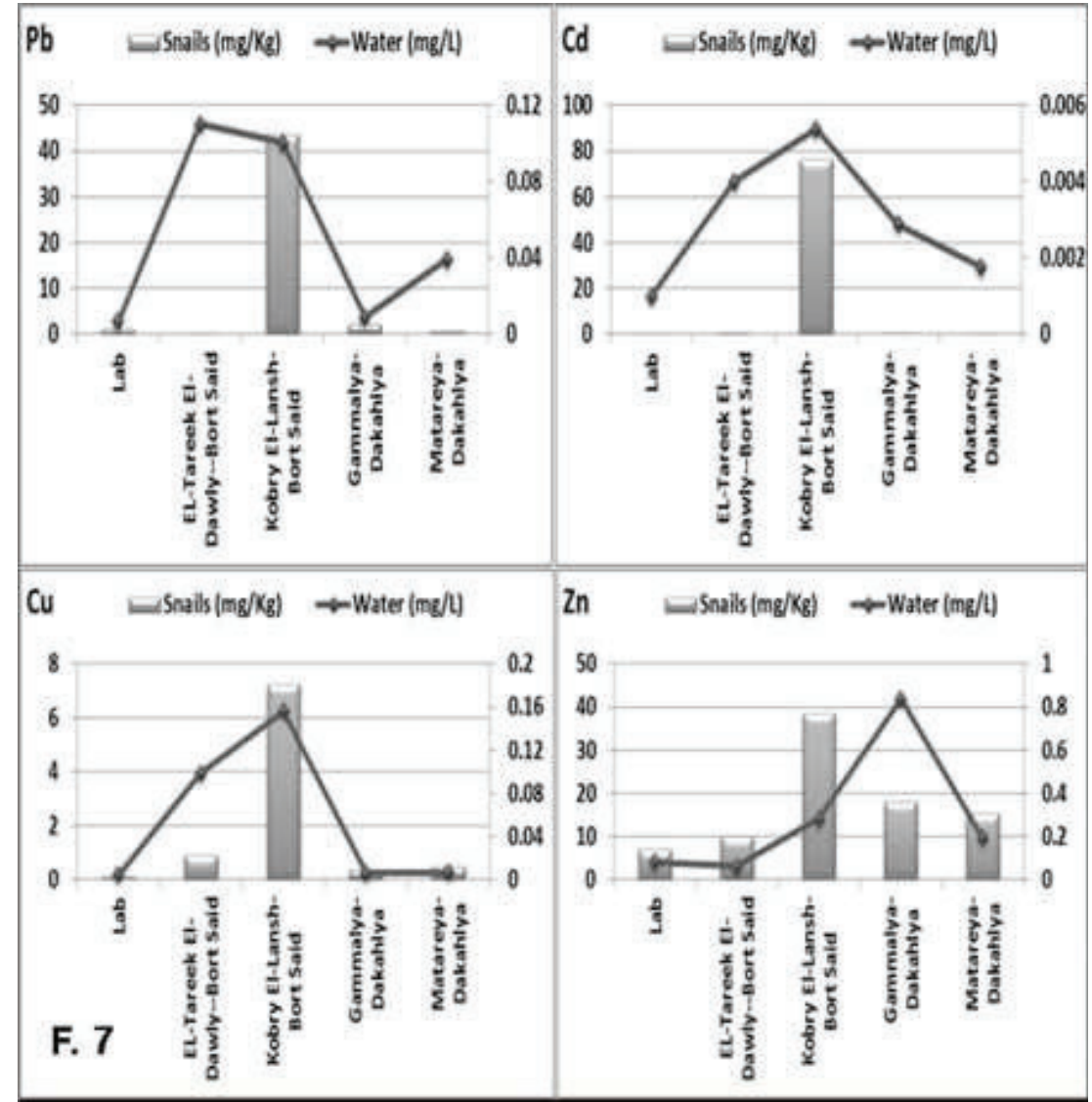

Fig. 7: Levels of cadmium $(\mathrm{Cd})$, copper $(\mathrm{Cu})$, lead $(\mathrm{Pb})$ and zinc $(\mathrm{Zn})$ in water samples and their residues in tissue of B. alexandrina and M. tuberculata collected from sites of Lake Manzala in Port-Said, Dakahlia and Damietta governorates and laboratory reared ones.

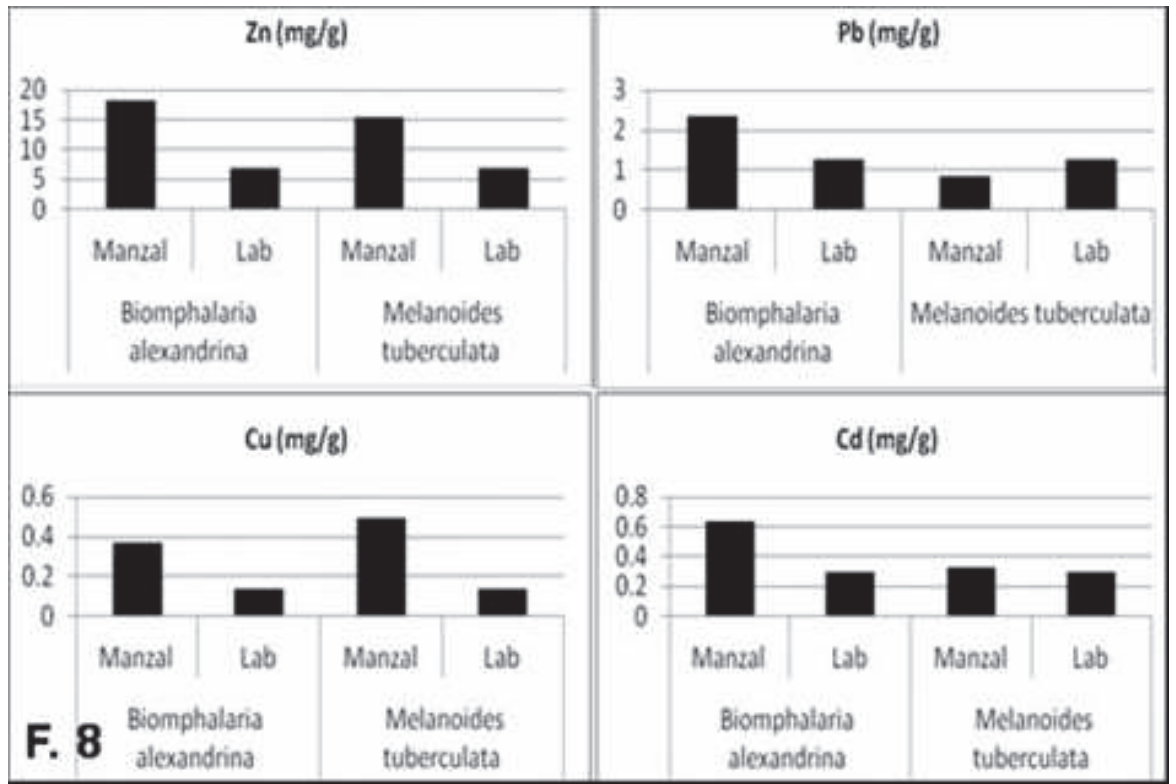

Fig.8: Residues of Cadmium $(\mathrm{Cd})$, copper $(\mathrm{Cu})$, lead $(\mathrm{Pb})$ and zinc $(\mathrm{Zn})$ in laboratory breeding snails, B. alexandrina and M. tuberculata and those collected from Lake Manzala in Dakahlia Governorate. 


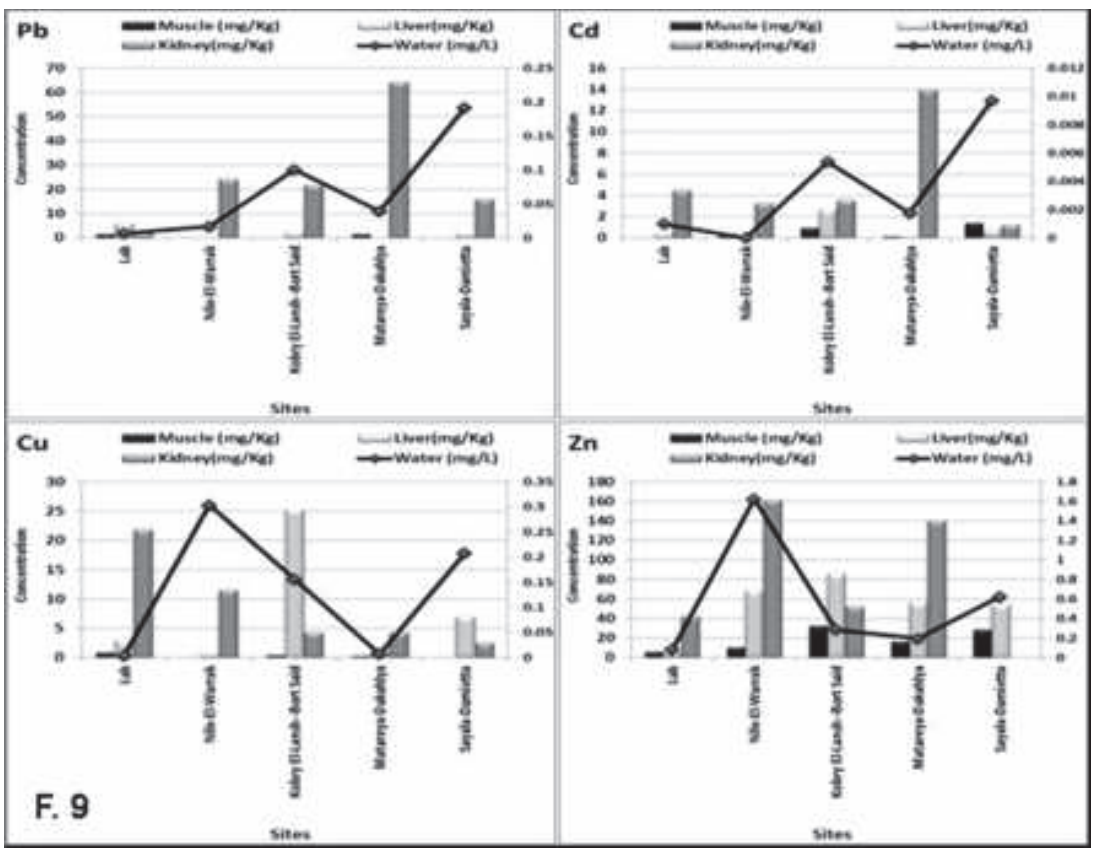

Fig. 9: Levels of cadmium $(\mathrm{Cd})$, copper $(\mathrm{Cu})$, lead $(\mathrm{Pb})$ and zinc $(\mathrm{Zn})$ in water samples and their residues in muscle, liver and kidney of Oreochromis niloticus fish samples (Family: Cichlidae) and laboratory reared ones.

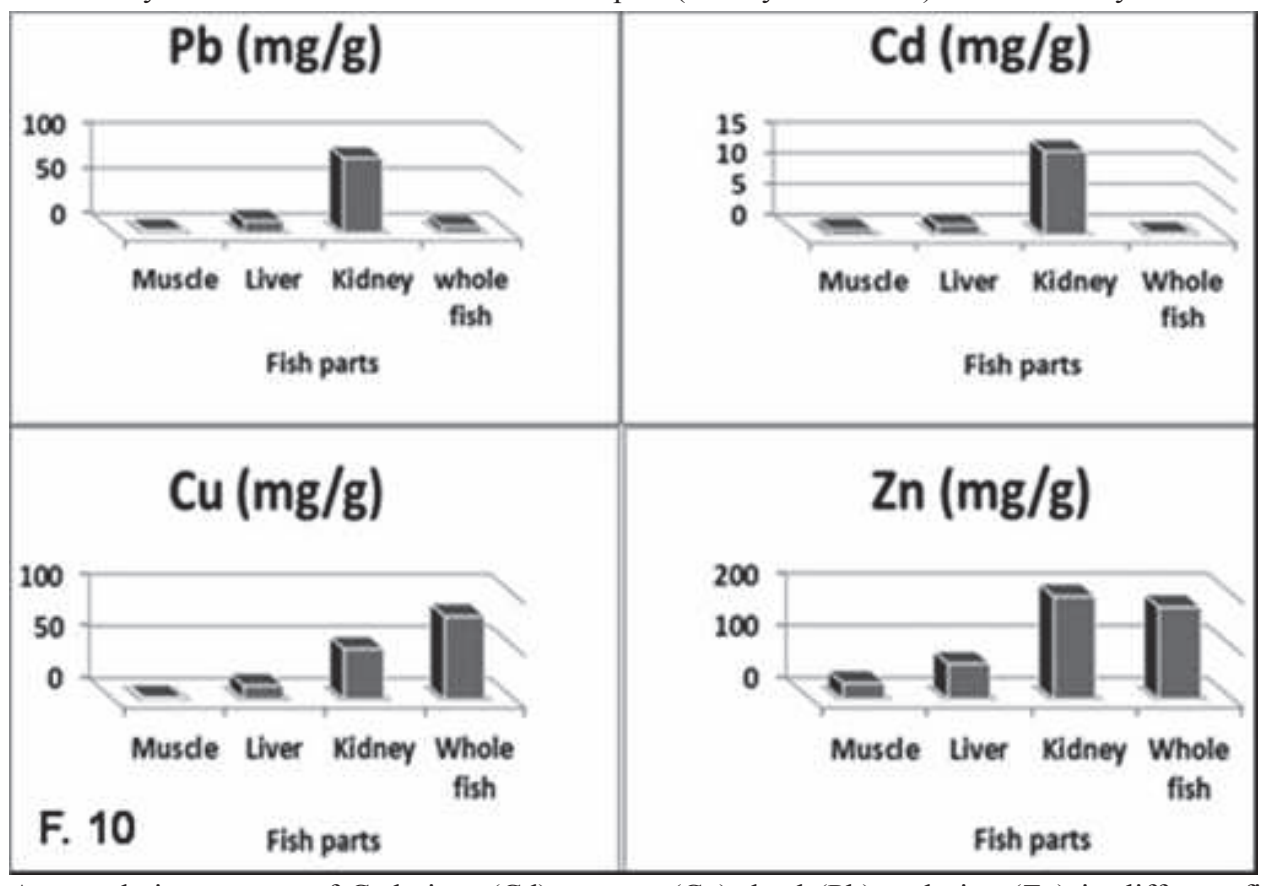

Fig. 10: Accumulation pattern of Cadmium $(\mathrm{Cd})$, copper $(\mathrm{Cu})$, lead $(\mathrm{Pb})$ and zinc $(\mathrm{Zn})$ in different fish parts; muscle, liver, kidney and whole fish; determined in $O$. niloticus fish samples collected from Lake Manzala.

Concentrations (Fig. 10) of $\mathrm{Pb}, \mathrm{Cd}, \mathrm{Cu}$ and $\mathrm{Zn}$ in the different examined fish tissues. Metal accumulated in the following orders: kidney $>$ liver $>$ whole fish $>$ muscle for $\mathrm{Pb}$, kidney $>$ liver $>$ muscle $>$ whole fish for $\mathrm{Cd}$, whole fish $>$ kidney $>$ liver $>$ muscle for $\mathrm{Cu}$ and kidney $>$ whole fish $>$ liver $>$ muscle for $\mathrm{Zn}$, the kidney and liver were the target organs in accumulation of heavy metals. The tissues of $O$. niloticus accumulated more heavy metals and the highest values were recorded in the tissues of fish from Dakahlia (Matarya site). 


\section{Discussion}

The present study concerned to address pollution impact on the ecosystem of Lake Manzala. It was noticed through the results of physico-chemical parameters that Lake Manzala sites in Damietta and Port-Said shared higher levels of dissolved oxygen, conductivity and heavy metals $(\mathrm{Pb}, \mathrm{Cd}$ and $\mathrm{Cu}$ ) than Dakahlia sites, which showed higher level of $\mathrm{Zn}$. This could be related to Damietta and Port-Said sites were more near to Mediterranean Sea, where water exchange takes place between the lake and sea across Strait El Gamil. Also, both Damietta and Port-Said sites are adjacent to industrial areas that adversely affect their water quality. On the other hand, Dakahlia sites more suffered from some point sources of pollution represented by some drains providing their habitat with the highest taxa richness of freshwater organisms including the three medically important snails, Biomphalaria, Bulinus and Lymnaea. Sites of Dakahlia and Port-Said, especially in the southern part, shared the active transmission of $S$. mansoni and the high distribution of the aquatic plant, $E$. crassipes. The recorded temperature in the present study ranged from $21-31^{\circ} \mathrm{C}$ that explained the abundance of gastropoda that tolerated to a wide range of temperature. This agreed with El-Emam and Roushdy (1981) who demonstrated that the optimum temperature for these mollusca lied between $22^{\circ} \mathrm{C}$ to $26^{\circ} \mathrm{C}$.

The present study recorded higher natural infection among collected Biomphalaria compared to other studies in watercourses reflected high risk of schistosomiasis transmission in the lake where people considering as safe water and where traditional methods of snail control couldn't be applied. ElHomossany (2006) showed that natural snail infection can occur in Nile especially in sites where fishing and agricultural activities, but mostly by low ratio, for $B$. alexandrina and $B$. truncatus snails $(0.71 \%$ and 0.29 , respectively). Also, El-Khayat et al., (2005) indicated that the natural infection among field
B. alexandrina snails collected from different localities was low (1.1). Haristone (1973) concluded that low percentage of natural infection is the rule (1-2\%), however high percentage (3.3-7.5) may be recorded in summer period suggestion that the proportion of snails infected with schistosome at any time depends upon complex interaction of different factors. Manzala sites in the three governorates shared the inhabiting of Biomphalaria where it was associated with E. crassipes in Dakahlya and Port-Said sites and with L. giba in Damietta sites. Biomphalaria is the only among medically important snails that could tolerated the higher levels of heavy metals that recorded in Port-Said and Damietta governorates suggesting its higher resistance to pollution impacts and environmental stressors. This suggestion was reinforced by El-Khayat et al. (2011a) found that $B$. alexandrina was significantly found to live under the highest level of $\mathrm{Pb}$, $\mathrm{Cd}, \mathrm{Cu}, \mathrm{Na}, \mathrm{K}$ and $\mathrm{Ca}$ concentrations than the other snail species $(\mathrm{p}<0.01)$. Also, ElKhayat et al. (2011b) studied the habitat characteristics for different freshwater snail species biologically through macroinvertebrate information and determined that $B$. alexandrina was the more distributed in sites that evaluated as very poor sites $(23 \%$ of their sites were evaluated as very polluted sites). Mahmoud (2001) commented that the adverse effects of water pollution on snail biology were modified by biotic factors including food supplies, aquatic plants, behavioral and physiological adaptation.

The present data of water analysis explored that all the measured heavy metals in Damietta and Port-Said sites and $\mathrm{Zn}$ and $\mathrm{Cd}$ in certain Dakahlya sites exceeded the limits determined EPA (2011). Also, the average of the four metals along the lake in the three studied governorates exceeded the recommended limits, this exhibited that Lake Manzala is polluted lake. This agrees with the demonstration that Lake Manzala receives huge amounts of sewage, industrial and agricultural wastes via Bahr El-Bakar 
drain, which collects these pollutants from different districts through its way from Cairo (Badawy and Wahaab, 1997; Abdel-Baky et al, 1998a, b; Ibrahim et al, 1999a; Bahnasawy, 2001; Bahnasawy et.al, 2009; Khalil and Faragallah, 2008). Moreover, Ali (2008) concluded that heavy metals discharged into the lake create a serious environmental problems, where the level of iron, manganese, lead and cadmium are exceeded the universal guidelines for water quality established by Environmental protection Agency.

In the present study, the concentration of the four measured metals was higher in $\mathrm{Bi}$ omphalaria and Melanoides tissues as compared to surface water. These results coincided with the highest levels of $\mathrm{Pb}, \mathrm{Cu} \& \mathrm{Cd}$ in water samples. This is in agreement with Mahmoud and Abu Taleb (2013) who studied the relationship between accumulations of $\mathrm{Cd}, \mathrm{Cu}$ and $\mathrm{Pb}$ in tissues of snails $C$. bulimoides, $H$. duryi, B. truncatus, B. alexandrina, $P$. acuta, B. unicolor and T. niloticus and its concentrations in water. They showed that the accumulations of $\mathrm{Cd}, \mathrm{Cu}$ and $\mathrm{Pb}$ in the tissues of snails were directly proportional with concentrations of these elements in the water from which these snails were harbored.

Heavy metals are known to be accumulated in fish tissues, reaching concentrations of up to 20000 fold higher than surrounding water environment (Popek et al, 2006). The present heavy metals accumulation pattern in different fish tissues of $O$. niloticus demonstrated that $\mathrm{Pb}$ and $\mathrm{Cd}$ are most accumulated in kidney, $\mathrm{Cu}$ is most accumulated in liver while $\mathrm{Zn}$ is accumulated in all examined parts with maximum accumulation in kidney. Western Australian Food and Drink Regulations recommended a level of $40 \mathrm{mg} /$ $\mathrm{kg} \mathrm{Zn}$ for human consumption (Marks et al, 1980). Accordingly, the concentrations of $\mathrm{Zn}$ in the muscles of the studied fish are still below the permissible level. Also, the concentrations of $\mathrm{Cu}$ in the muscles of the studied fish are still below the permissible level for $\mathrm{Cu}(30 \mathrm{mg} / \mathrm{kg})$ recommended by the $\mathrm{Na}-$ tional Health and Medical Research Council (Marks et al, 1980). Kotze et al. (1999) and Canli and Atli, (2003) interpreted that the difference in the levels of accumulation in different organs tissue of fish can be attributed primarily to the differences in the physiological role of each organ. Also, regulatory ability, behavior and feeding habits are other factors that influence the accumulation differences in different organs. This is confirmed by the findings of Abdel-Moneim et al., (1994) who reported that, target organs, such as the liver and gills, are metabolically active tissues and accumulate heavy metals in higher levels, as shown in many species of fish, Mugil cephalus in the Mediterranean Sea, Clarias gariepinus and Labeo umbratus from Olifants River, South Africa (Coetzee et al., 2002) and Tilapia zilli from River Nile (Hamed, 1998). The present highest accumulation of $\mathrm{Cu}$ in fish liver was interpreted by El-Shahawi and Yousuf (1998) and Abdel-Baky (2001) who stated that the high accumulation of $\mathrm{Cu}$ in the liver could be attributed to the specific metabolic processes and enzyme catalyzed reaction involving $\mathrm{Cu}$ taking place in the liver. Also, the sulfur legends in the liver have a great tendency to co-ordinate with $\mathrm{Cu}$ via oxygen carboxylate amino group nitrogen and/or sulfur of the mercapto group in the metallothionein protein which is in the highest concentration in the liver. Also, the present least bioaccumulation for all the measured metals in fish muscles was confirmed; Zaghloul et al, (2007) who studied heavy metals $(\mathrm{Cu}, \mathrm{Pb}, \mathrm{Zn}$ and $\mathrm{Mn})$ accumulation in some selected vital organs (gills, liver, kidney and muscle) of the Nile tilapia; $O$. niloticus collected from the different sites along El-Burullus Lake and declared that the lowest concentrations of the studied heavy metals accumulated in muscle. Also, Bahnasawy et al. (2009) found that muscles contained the lowest levels of heavy metals in the examined fish $M$. cephalus and $L$. ramada. Soltan et al. (2005) and Fernandes et al. (2008) found that $\mathrm{Cu}$ exhibited its highest 
levels in the liver and the lowest values in the muscles. Furthermore, many authors reported that muscle was not an active tissue in accumulating heavy metals (Ibrahim et al, 1999a, b; Canli and Atli, 2003; Karadede et al, 2004; Yilmaz, 2005; Chouba et al, 2007).

\section{Conclusion}

The outcome results proved that the concentrations of metals in the studied fish tissues were dependent upon the target organ as well as the type of metal. Generally, the studied metals were more concentrated in the non-edible parts of the fish than the edible muscles. $\mathrm{Zn}, \mathrm{Cu}, \mathrm{Pb}$ and $\mathrm{Cd}$ concentrations in the muscles were within the maximum permissible limit. It is clear that the tissues of snails accumulated more metals than fish O. niloticus. Thus, Public Health and Agricultural Authorities must keep into consideration the heavy metals in fishes and their impact on human health and economy.

\section{Acknowledgement}

This study is a joint project (Biomarkers as indicators of environmental pollution: Experimental approach and case studies), kindly funded by the Academy of Scientific Research and Technology through the Bilateral Agreement between Academy of Scientific Research and Technology of the Arab Republic of Egypt and Bulgarian Academy of Sciences, 2012-2014.

\section{References}

Abdel-Baky, TE, 2001: Heavy metals concentrations in the catfish Clarias gariepinus (Burchell, 1822) from River Nile, El-Salam Canal and Lake Manzala and their impacts on cortisol and thyroid hormones. Egypt. J. Aquat. Biol. Fish. 5:79-98.

Abdel-Baky, TE, Hagras, AE, Hassan, SH, Zyadah, MA, 1998a: Environment assessment of pollution in Lake Manzala. 1- Distribution of some heavy metals in water and sediment. J. Egypt. Ger. Soc. Zool. 26, B:25-38.

Abdel-Baky, TE, Hagras, AE, Hassan, SH, Zyadah, MA, 1998b: Heavy metals concentration in some organs of Oreochromis aureus stein in Lake Manzala, E Egypt. J. Egypt. Ger. Soc. Zool. 25, A:237-56.
Abdel Moneim, M, Khaled, A, Iskander, M, 1994: A study on the levels of some heavy metals in EL-Max, west of Alexandria, Egypt .The $4^{\text {th }}$ conf. Environ. Prot. is a must, 10-12 May, Egypt.

Abdel Satar, AM, 2001: Environmental studies on the impact of the drains effluent upon the southern sector of Lake Manzala, Egypt, Egypt. J. Aquat. Biol. Fish. 5, 3:17-30.

Ali, MHH, 2008: Assessment of some water quality characteristics and determination of some heavy metals in Lake Manzala, Egypt. Egypt. J. Aquat. Biol. Fish. 12, 2:133-54.

Altinda ğ, A, Yiğit, S, 2005: Assessment of heavy metal concentrations in the food web of Lake Beyšehir, Turkey. Chemosphere 60: 552-6.

Aseeb, AN, EL-Shazly, AM, Arafa, MA, Morsy, AT, 2002: A review on fascioliasis in Egypt. J. Egypt. Soc. Parasitol. 32, 2:317-54.

Awad, WSA, Ibrahim, AK, EL Sayed, MM, 2004: Comparing coprological examination and indirect enzyme linked immunosorbent assay for studying fascioliasis in Egyptian donkeys. J. Egypt. Vet. Med. Assoc. 64:65-72.

Badawy, MI, Wahaab, RA, 1997: Environmental impact of some chemical pollutants on Lake Manzala. Int. J. Environ. Hlth. Res. 7:16170.

Bahnasawy, M, 2001: Levels of heavy metals in cat fish, Clarias gariepinus, from different habitats and their effects on some biochemical parameters. Egypt. J. Aquat. Biol. Fish. 5, 1: 99125.

Bahnasawy, M, Khidr, A, Dheina, N, 2009: Seasonal Variations of Heavy Metals Concentrations in Mullet, Mugil Cephalus and Liza Ramada (Mugilidae) from Lake Manzala, Egypt. J. Appl. Sci. Res. 5, 7:845-52.

Bailey, NT, 1981: Statistical Methods in Biology. $2^{\text {nd }}$ edition (Biological Science Texts)

Bishai, HM, Yossef, SF, 1977: Some aspects on the hydrography, physicochemical, characteristics and fisheries of Lake Manzala. Bull. Inst. Oceanogra. Fish. 7, 1:32-58.

Bouchard, RWJ, 2004: Guide to Aquatic macroinvertebrates of the Upper Mid-west: Water Resources Center, University of Minnesota.

Buss, DF, Borges, EL, 2008: Application of rapid biossessment protocols (R B P) for benthic macroinvertebrates in Brazil: Comparison between sampling techniques and mesh size. Neotrop. Entomol. 37, 3:288-95. 
Canli, M, Atli, G, 2003: The relationships between heavy metal $(\mathrm{Cd}, \mathrm{Cr}, \mathrm{Fe}, \mathrm{Pb}, \mathrm{Zn})$ levels and the size of six Mediterranean fish species. Environ. Pollut. 121:129-36.

Chouba, L, Kraiem, M, Njimi, W, Tissaoui, C, Thompson, J, et al, 2007: Seasonal Variation of heavy metals $(\mathrm{Cd}, \mathrm{Pb}, \& \mathrm{Hg})$ in sediments and mullet, Mugil cephalus (Mugilidae) from the Ghar EL-Melh Lagoon (Tunisia). Transit. Water Bull.4:45-52.

Coetzee, L, du Preez, HH, van Vuren, JH, 2002: Metal concentrations in Clarias gariepinus and Labeo umbratus from the Olifant and Klein Olifants River, Mpumalanga, South Africa: Zinc, copper, manganese, lead, chromium, nickel, aluminium and iron. Water SA, 28, 4: 433-48.

El-Baz, MA, Morsy, M, EL-Bandary, M, Motaweae, SM, 2003: Clinical and parasitological studies on the efficacy of Mirazid in treatment of Scistosomiasis haematobium in Tatoon, Esta center, El-Fayoum Governorate. J. Egypt. Soc. Parasitol. 33:761-76.

El-Emam, MA, Roushdy, MZ, 1981: Ecological studies on snail intermediate hosts of Schistosomes in certain areas in Egypt. Egypt J. Bilh. 8:75- 86.

El-Khayat, HMM, Saber, MA, Abu ElHassan, A, 2005: Study of the susceptibility of the Biomphalaria alexandrina collected from five localities in Egypt to infection with local strains of Schistosoma mansoni. Egypt. J. Schisto Infect. End. Dis. 27:39-50.

El-Khayat, HMM, Ismail, NM, Mahmoud, KM, Ragb, FM, El-Said, KM, et al, 2011a: Evaluation of some chemical parameters as potential determinants of fresh water snails with special reference to medically important snails in Egypt. International Conference on System Biology (ICSB) - Venise-Italy 28-30 Nov. 2011, Waste Proceed. 59:1313-26.

El-Khayat, HMM, Mahmoud, KM, Mostafa, BB, El-Deeb, FA, Tantawy, AA, et al, 2011b: Habitat characteristics for different freshwater snail species as determined biologically through macroinvertebrate information. Egypt. J. Egypt. Soc. Parasitol. 41, 3:651-64.

El-Shahawi, M, Yousuf, M, 1998: Heavy metal $(\mathrm{Ni}, \mathrm{Co}, \mathrm{Cr}$ and $\mathrm{Pb})$ contamination in liver and skin of Lethrinus lentjan fish family: Lethrinidae (Teleost) from the Arabian Gulf. Int. J. Food Sci. Nutrit.49:447-51
EL-Shazly, AM, Abdel-Magied, AA, ELNahas, HA, EL-Metwaly, MS, Morsy, TA, et al, 2005: On the main reservoir host of Fasciola in Dakahlia Governorate, Egypt. J. Egypt. Soc. Parasitol. 35, 2:243-52.

EPA, 2011: (United States Environmental protection Agency) National Recommended Wat-er Quality Criteria. http://water.epa.gov/scitech/ swguidance/standards/criteria/current/index. cfm FAO, 1983: Compilation of legal limits for hazardous substances in fish and fishery products. FAO Fishery Circular No. 464:5-100.

Fernandes, C, Fontainhas-Fernandes, A, Cabral, D, Salgado, M, 2008: Heavy metals in water, sediment and tissues of Liza saliens from Esmoriz-Paramos lagoon, Portugal. Environ. Monit. Assess. 136:267-75.

Hamed, M, 1998: Distribution of trace metals in the River Nile Ecosystem, Damietta branch between Mansoura city and Damietta Province. J. Egypt. Ger. Soc. Zool. 27, A:399-415.

Haridy, FM, El-Sherbiny, GT, Morsy, TA, 2006: Some parasitic flukes infecting farm animals in Al- Santa Center, Gharbia Governorate, Egypt. J. Egypt. Soc. Parasitol. 36:259-64.

Hariston, NG, 1973: The dynamics of transmission. In: Epidemiology and Control of Schistosomiasis: Bilharziasis. Published on behave of WHO by Schistosoma Karger. Basel. Munchen.

Haur, RF, Lamberti, GA, 1996: Methods in stream ecology. In: Benthic Macro-invertebrate. Academic Press, San Diego, New York.

Ibrahim, A, Bahnasawy, M, Mansy, S, ELFayomy, R, 1999a: Heavy metal accumulation in water, sediment and some fishes in Lake Manzala, Egypt. J. Egypt. Ger. Soc. Zool. 29, B: 43-58.

Ibrahim, A, Bahnasawy, M, Mansy, S, ElFayomy, R, 1999b: Distribution of heavy metals in the Damietta Nile Estuary ecosystem. Egypt. J. Aquat. Biol. Fish. 3, 4:369-97.

Karadede, H, Oymak, SA, Ünlü, E, 2004: Heavy metals in mullet, Lizaabu, and Catfish, Silurus triostegus, from the Ataturk Dam Lake (Euphrates), Turkey. Environ. Int. 30:183-8.

Khalil, M, Faragallah, H, 2008: The distribution of some leachable and total heavy metals in core sediments of Manzala lagoon, Egypt. Egypt. J. Aquat. Res. 34, 1:1-11.

Kotze, P, du Preez, HH, van Vuren, JHJ, 1999: Bioaccumulation of copper and zinc in Oreochromis mossambicus and Clarias gariepi- 
nus from the Olifants River, Mpumalanga, South Africa. Water SA 25, 1:99-110.

Leska, SF, 1998: Guide to fresh water invertebrates at www.seanet.com.leska.

Madsen, JD, 1994: Aquatic Botany, New York State Department of Environmental, 41:195-224.

Mahmoud, AAF, 2001: the schistosomes and their intermediate hosts. In: Schistosomiasis. Pasvol, G. and Hofffman, S.L (eds) Imperical College Press, London.

Mahmoud, KMA, Abu Taleb, HMA, 2013: Fresh water snails as bio-indicator for some heavy metals in the aquatic environment. Afr. J. Ecol. 51:193-8

Marks, PJ, Plaskett, D, Potter, I, Bradley, J, 1980: Relationship between concentration of heavy metals in muscle tissues and body weight of fish from the Swan-Avon estuary, Western Australia. Austral. J. Mar. Freshwater Res. 31:783-93.

Mazyad, SA, EL-Nemr, HI, 2002: The endoparasites of sheep and goats and shepherd in North Sinai Governorate, Egypt. J. Egypt. Soc. Parasitol. 32, 1:119-26.

Mohamed, FA, Aboul-Ezz, AS, 2006: Distribution pattern of some heavy metals in tissues of some fish species from the Mediterranean Sea. Afri. J. Biol. Sci. 2:105-19.

Morsy, TA, Salem, HS, Haridy, FM, Rifaat, MM, Abo-Zenadah, NY, et al, 2005: Farm animals' fascioliasis in Ezbet El-Bakly (Tamyia Center) Al-Fayoum Governorate. J. Egypt. Soc. Parasitol. 35, 3:825-32.

Muncaster, BW, Hebert, PDN, Lazar, R, 1990: Biological and physical factors affecting the body burden of organic contaminants in freshwater mussels. Arch. Environ. Cont. Toxicol. 19:25-34.

Popek, W, Dietrich, G, Glogowski, J, Demska-Zakes, K, Drag-Kozak, E, et al, 2006: Influence of heavy metals and 4-nonylphenol on reproductive function in fish. Reprod. Biol. 6: $175-88$

Porte, C, Albaiges, J, 1993: Bioaccumulation patterns of hydrocarbons and polychlorinated biphenyls in bivalves, crustaceans and fish. Arch. Environ. Contam. Toxicol. 26:273-81.

Robinson, BA, 2004: An Inventory of aquatic macroinvertebrate and calculation of selected
Biotic Indices for the U.S. Army Atterbury Reserve Forces Training Area near Edinburgh, Indiana, Scientific Investigations Report.

Silveira-Coffigny, R, Prieto-Trujillo, A, Ascencio-Valle, F, 2004: Effects of different stressors in hematological variables in cultured Oreochromis aureus. Comp. Biochem. Physiol. C Toxicol. Pharmacol. 139, 4:245-50.

Sola, CM, Burgos, PA, Taja, J, Plans, M, Prat, N, 2004: Heavy metal bioaccumulation and macroinvertebrates community changes in a Mediterranean stream affected by acid mine drainage and an accidental spill (Guadiamar River, SW Spain). Sci. Total Environ. 15:10926.

Soltan, M, Moalla, S, Rashed, M, Fawzy, E, 2005: Physicochemical characteristics and distribution of some metals in the ecosystem of Lake Nasser, Egypt. Toxicol. Environ. Chem. 87:167-97.

Stone, ML, Whiles, MR, Webber, JA, Williard, KW, Reeve, JD, 2008: Macro-invertebrate communities in agriculturally impacted southern lllinois streams patterns with riparian vegetation, water quality and in-stream quality. J. Environ. Qual. 34, 3:907-17.

Takougang, I, Barbazan, P, Tchou- nwou, PB, Noumi, E, 2008: The value of the freshwater snail dip scoop sampling method in macroinvertebrates bio-assessment of sugar mill waste-water pollution in Mbandjock, Cameroon. Int. J. Environ. Res. Pub. Hlth. 5, 1:68-75.

Van Damme, PA, Hamel, C, Ayala, A, Bervotes, L, 2008: Macroinvertebrate community response to acid mine drainage in rivers of the Hig Andes (Bolivia). Environ. Pollut. 56:1061-8. WHO, 2007: Report of the WHO Informal Meeting on Use of Triclabendazole in Fascioliasis Control: WHO/CDS/ NTD/PCT/1.

Yilmaz, BA, 2005: Comparison of Heavy metal levels of grey Mullet (Mugilcephalus) and sea Bream (Sparus aurata) caught in Iskenderun Bay (Turkey).Turk. J. Vet. Anim. Sci. 29:25762.

Zaghloul, KH, Hasheesh, WS, Zahran, IA, Marie, MS, 2007: Ecological and biological studies on the Nile tilapia Oreochromis niloticus along different sites of Lake Burullus. Egypt. J. Aquat. Biol. Fish. 11, 3:57-88. 